\title{
BAGAIMANA INOVASI GAGAL: PEMBELAJARAN DARI KLASTER INDUSTRI SARUNG MAJALAYA
}

\author{
Nabilla Dina Adharina 1 ${ }^{a}$, Puni Seruni $2^{\text {b }}$ \\ alnstitut Teknologi Nasional Bandung; Jl. PH.H. Mustofa No.23 Bandung 40124; adharinabil@itenas.ac.id \\ bBadan Perencanaan, Penelitian dan Pengembangan Daerah Kabupaten Bandung; Jl. Raya Soreang km.17 40912 ; \\ puni.bubu@gmail.com
}

Info Artikel:

- Artikel Masuk: 14/09/2020
- Artikel diterima: $10 / 10 / 2020$
- Tersedia Online: 30/10/2020

\begin{abstract}
ABSTRAK
Pentingnya peran inovasi dalam mendorong pertumbuhan ekonomi menekankan kebutuhan lokal dan wilayah untuk menciptakan lingkungan yang nyaman bagi perkembangan inovasi. Klaster industri, melalui kedekatan spasialnya menjanikan lingkungan yang dapat memelihara perkembangan inovasi. Namun, menggunakan kasus klaster industri Sarung Majalaya, dengan pendekatan deduktif dan metode kualitatif, penelitian ini mendapatkan bahwa kedekatan spasial bukan satu-satunya faktor yang mendorong terjadinya inovasi. Terdapat faktor-faktor non-fisik yang memiliki peran penting di dalam proses difusi pengetahuan, yaitu proses yang menghasilkan inovasi. Faktor tersebut adalah kemampuan dalam memperoleh, mengasimilasi, dan transformasi pengetahuan baru. Kemampuan tersebut mewakili kemampuan serap atau daya serap dalam proses difusi pengetahuan. Keterbatasan kemampuan individu, kolektif, dan lingkungan pada kapasitas tersebut menyebabkan proses difusi pengetahuan terhambat dan inovasi tidak berkembang di dalam klaster industri Sarung Majalaya. Sebagai pertimbangan kebijakan, mendorong inovasi dalam klaster dapat dilakukan melaui pengembangan infrastruktur, baik infrastruktur dasar serta infrastruktur di bidang penelitian dan pengembangan yang berkaitan dengan industri di dalamnya. Selain itu, adaptasi kolektif juga ternyata penting dalam proses difusi pengetahuan sehingga kapasitas sosial pelaku ekonomi di dalam kawasan perlu diderkuat.
\end{abstract}

Kata Kunci : Klaster, difusi pengetahun, inovasi

\section{ABSTRACT}

The importance of innovation in driving economic growth emphasizes the need for local and regional to create a convenient environment for innovation development. Industrial cluster, through spatial proximity, promises the environment nurturing innovation. However, by using industrial klaster of Sarung Majalaya, incorporating a deductive approach and qualitative method, this study found that spatial proximity is not the only factor promoting innovation. There are non physical factors playing important role in a process named knowledge diffusion which creates innovation. They are the capacities of knowledge acquirement, knowledge assimilation, and knowledge transformation which represent the absortive capacity in knowledge diffusion. As a policy consideration, promoting innovation within cluster can be conducted by developing basic infrastructure as well as research and development infrastructure. Furthermore, collective adaptation also plays an important role in the process of knowledge diffusion hence social capacity in the cluster should be strengthened.

Keyword: Kluster, knowledge diffusion, innovation

\section{PENDAHULUAN}

Sarung Tenun Majalaya merupakan produk lokal yang dihasilkan oleh industri kecil dan menengah yang beraglomerasi di Kecamatan Majalaya. Kawasan ini berada 25 $\mathrm{km}$ dari pusat Kota Bandung. Pertama berkembang di tahun 1920, Sarung Majalaya pernah menjadi sarung populer di tingkat Asia dan mendominasi permintaan sarung nasional sebesar 47\% ( Lauwis, 2016; Lestari \& Siagian, 2018). Kini situasi sudah berubah, produktifitas dan popularitas Sarung Majalaya telah menurun. Globalisasi menyebabkan kompetisi pada produk tekstil Indonesia semakin agresif di berbagai skala. Jika dibandingkan dengan sarung merek ternama yang diproduksi di Jawa Tengah dan Jawa Timur, Sarung Majalaya menunjukan inovasi produk yang terbatas. Hal tersebut dapat dilihat dari variasi motif, warna, dan produk turunan yang lebih sedikit dibandingkan dengan produk sarung yang kini populer di kalangan masyarakat. Hal tersebut merupakan salah satu alasan mengapa Sarung Majalaya tidak lagi unggul di pasar lokal, nasional, dan global. Sekarang, Sarung Majalaya dikenal sebagai sarung "murah" 
dengan tujuan pasar kelas bawah dan menengah.

Inovasi memiliki peran kunci sebagai mesin dalam pertumbuhan ekonomi lokal dan wilayah (Chen et al., 2009; Henderson \& Weiler, 2010). Bahkan, Porter (2000) berargumen bahwa keberadaan klaster dapat mendorong terjadinya inovasi melalui kedekatan spasial. Kedekatan spasial mendorong inovasi dengan menciptakan lingkungan yang kondusif untuk terjadinya difusi pengetahuan melalui interaksi dan kolaborasi. Komunikasi intensif antar pelaku mendorong terjadinya difusi pengetahuan (Aiginger \& Rossi-Hansberg, 2006; Malmberg et al., 1996). Difusi pengetahuan dicirikan oleh adanya pihak yang mengadopsi pengetahuan baru kemudian pengetahuan tersebut ditransfer kepada pihak lain (Klarl, 2009). Proses penyebaran pengetahuan baru tersebut mendorong terjadinya tindakan inovasi kemudian semakin pengetahuan baru tersebar secara luas, inovasi dalam skala yang lebih luas mungkin terjadi. Difusi pengetahuan itu sendiri ternyata ditentukan kapasitas serap baik lingkungan dan pelaku terhadap pengetahuan baru. (Chen et al., 2009; Klarl, 2009). Kapasitas tersebut dilihat dari kemampuan lingkungan dan pelaku ekonomi baik secara individu maupun kelompok dalam memperoleh, megasimilasi, mengubah, dan menerapkan atau mengeksploitasi pengetahuan (Hotho et al., 2012).

Frustasi terhadap inovasi produk Sarung Majalaya yang terjadi pada klaster sarung di Kecamatan Majalaya mengindikasikan bahwa kedekatan spasial tidak menjadi satu-satunya faktor yang menjamin terjadinya inovasi. Terdapat faktor lain yang mempengaruhi proses difusi pengetahuan pada lingkungan klaster industri Sarung Majalaya sehingga inovasi tidak terjadi secara signifikan.

Dengan pendekatan studi kasus dengan kasus klaster Sarung Tenun Majalaya, penelitian ini bertujuan untuk mengidentifikasi sejauh mana kapasitas serap tersebut mampu menentukan kesuksesan difusi pengetahuan sebagai proses penting dalam menciptakan inovasi produk. Kapasitas serap ini akan diidentifikasi melalui beberapa kemampuan, yaitu kemampuan memperoleh, mengasimilasi, dan mengubah pengetahuan baru. Analisis terbagi menjadi dua bagian. Analisis pertama yaitu analisis kemampuan memperoleh pengetahuan baru kemudian analisis yang ke dua adalah kemampuan asimilasi dan transformasi pengetahuan baru. Masing-masing kemampuan tersebut akan dilihat sejauh mana berdampak terhadap proses difusi pengetahuan di dalam klaster industri Sarung Majalaya yang merupakan proses penting dalam melahirkan inovasi di suatu kawasan. Penelitian ini penting sekali dilakukan mengingat masih terbatasnya penelitian yang fokus terhadap proses difusi pengetahuan dalam membahas inovasi pada klaster industri, terutama industri kecil dan mengenah di Indonesia. Penelitian ini akan memberikan wawasan baru mengenai pengembangan inovasi dalam klaster sebagai upaya mendorong pertumbuhan ekonomi lokal dan wilayah.

\section{DATA DAN METODE}

Penelitian ini merupakan penelitian studi kasus dengan metode penelitian kualitatif. Pendekatan deduktif dimulai dengan membangun kerangka konseptual mengenai faktor-faktor yang mempengaruhi difusi pengetahuan melalui kajian literatur yang sistematik. Data dan informasi didapatkan langsung melalui wawancara mendalam, narasumber dipilih secara purposive sampling dan snowball sampling. Narasumber yang dipilih berdasarkan purposive sampling memiliki kriteria yaitu, memahami awal dan kondisi terkini perkembangan industri Sarung Majalaya dan/atau pemilik industri Sarung Majalaya yang sudah lama berdiri. Selain itu, informasi juga didapatkan melalui diskusi kelompok terarah yang dihadiri baik oleh pelaku industri yang telah diwawancara maupun belum diwawancara. Sebagai upaya meningkatkan validitas penelitian, triangulasi hasil analisis dilakukan dengan mewawancarai perwakilan Dinas Perdagangan dan Perindustrian Kabupaten Bandung.

\section{GAMBARAN UMUM KASUS}

Bagian ini akan menjelaskan gambaran terkait klaster industri Sarung Majalaya yang dilihat dari karakter pelaku industri, kondisi 
pemasaran Sarung Majalaya, dan keterbatasan inovasi pada produk Sarung Majalaya.

\subsection{Karakter Industri dan pemilik industri Sarung Majalaya}

Industri Sarung Majalaya merupakan usaha keluarga sehingga kegiatan-kegiatan di dalamnya dikelola oleh anggota keluarga, terutama pada kegiatan pemasaran dan penjualan. Kegiatan lainnya seperti produksi, pengawasan dan pemeliharaan mesin dilakukan oleh pagawai yang dipekerjakan. Usaha industri Sarung Majalaya tidak hanya usaha yang dilakukan untuk memenuhi kebutuhan keluarga. Industri Sarung Majalaya merupakan warisan dari generasi ke generasi. Meneruskan usaha industri Sarung Majalaya menjadi amanat yang perlu dijaga apalagi Sarung Majalaya juga merupakan identitas masyarakat Majalaya. Industri Sarung Majalaya, pada umumnya dijalankan oleh laki-laki dengan usia di atas 45 tahun. Dalam menjalankan usaha industri Sarung Majalaya, pemilik industri tidak mengambil pendidikan formal atau informal di bidang bisnis maupun bidang tekstil. Selain itu, mereka memiliki pendidikan terakhir yang beragam, seperti sekolah menengah pertama dan sekolah menengah akhir.

\subsection{Pemasaran Sarung Majalaya}

Sarung Majalaya dijual kepada pasar kelas mengenah dan bawah, terutama di Jakarta, Surabaya, dan Makasar. Terdapat dua cara utama dalam memasarkan Sarung Majalaya. Pertama, mereka menjual sarung tanpa merek dalam skala besar. Kondisi ini banyak sekali ditemukan pada industri sarung Majalaya. Sebelum dijual oleh pengumpul, sarung tersebut diberikan merek yang dimiliki oleh pengumpul kemudian dijual dengan harga yang lebih tinggi. Salah satu alasan mengapa sarung yang diproduksi tidak memiliki merek adalah kesulitan pemilik industri dalam mendaftarkan merek dan tingginya biaya yang dibutuhkan.

Cara penjualan selanjutnya adalah menjual Sarung Majalaya langsung ke toko-toko sarung yang kebanyakan berada di luar Kota Bandung dan Kabupaten Bandung, seperti Jakarta. Pelaku usaha industri Sarung Majalaya yang memiliki merek sarung sendiri biasanya menjual dengan cara ini. Kebanyakan dari mereka tidak memiliki toko sendiri yang memperlihatkan dan menjual produk-produk sarung yang mereka hasilkan langsung kepada calon pembeli. Jika terdapat calon pembeli sarung yang berjalan-jalan ke Kecamatan Majalaya dan ingin membeli sarung sebagai buah tangan, mereka akan kesulitan karena hampir tidak ada pusat perbelanjaan atau toko yang menjual Sarung Majalaya. Jika mengunjungi mereka mencoba untuk membeli Sarung Majalaya dengan mengunjungi langsung tempat produksi sarung, mereka akan kesulitan untuk membeli dalam jumlah yang sedikit.

\subsection{Terbatasnya Inovasi pada Produksi Sarung Majalaya}

Sarung Majalaya memiliki motif khas yang menjadi ciri dari Sarung Majalaya. Walaupun begitu, dari waktu ke waktu motif Sarung Majalaya berkembang sebagai upaya bertahan di tengah persaingan dengan sarung-sarung bermerek yang lebih dikenal oleh masyarakat. Namun, perkembangan motif Sarung Majalaya cenderung mengikuti motif dari sarung-sarung bermerek tersebut. Pelaku industri Sarung Majalaya berargumen bahwa dengan mengikuti motif dari sarung bermerek tersebut, mereka diuntungkan dari permintaan pembeli yang menginginkan motif sarung yang sama dengan motif sarung bermerek namun dengan harga yang jauh lebih murah. Pelaku industri Sarung Majalaya juga menyatakan diri mereka sendiri sebagai follower, meskipun mereka mengakui bahwa menciptakan motif sendiri lebih baik tetapi mereka sadar bahwa mereka memiliki kemampuan yang baik untuk dapat membuat motif yang sama dengan motif sarung yang sedang banyak diminati. Kemampuan tersebut sayangnya, tidak dimanfaatkan untuk mencoba menciptakan pasar yang baru melalui motif baru karena mereka cenderung lebih suka mengisi pasar yang sudah ada.

Selain itu, jarang sekali ditemukan turunan produk sarung Majalaya, seperti pakaian, tas, atau sepatu sebagaimana dapat ditemukan di daerah-daerah penghasil kain tenun di Nusa Tenggara Barat dan Nusa Tenggara Timur. Padahal jika di kawasan klaster industri Sarung Majalaya juga berkembang industri-industri yang menghasilkan produk turunan Sarung 
Majalaya yang menarik dan diterima baik oleh pasar. Produksi Sarung Majalaya itu sendiri juga dapat terus berkembang. Kini kondisi yang terjadi adalah lesunya permintaan Sarung Majalaya menyebabkan beberapa industri sarung terpaksa gulung tikar dan ini juga berdampak kepada industri lainnya yang terkait, seperti industri pewarnaan dan benang yang juga awalnya banyak berkembang di Majalaya.

\section{HASIL DAN PEMBAHASAN}

Hasil dan pembahasan akan dibagi berdasarkan tiga kemampuan, yaitu kemampuan individu dan lingkungan mendapatkan pengetahuan baru, kemampuan asimilasi pengetahuan baru serta transormasi pengetahuan baru. Pembahasan terkait asimilasi dan transformasi pengetahuan baru akan dibahas pada bagian yang sama karena adanya keterkaitan yang erat antar dua kemampuan tersebut.

\subsection{Kemampuan dalam Memperoleh Pengetahuan Baru}

Saluran informasi memiliki peran penting dalam mendorong terjadinya inovasi mengingat, berbagai studi mendapatkan bahwa inovasi dimulai dari pengetahuan yang berasal dari luar perusahaan atau bahkan internal kawasan (Chen et al., 2009; Cohen \& Levinthal, 1990; Malmberg et al., 1996; Mitra, 2000). Informasi yang berasal dari luar kawasan tersebut kemudian diadopsi dan ditransfer kembali kepada pelaku ekonomi yang ada di dalam perusahaan atau kawasan. Berdasarkan hal tersebut, maka kemampuan individu dan lingkungan dalam mendapatkan pengetahuan baru dilihat dari bagaimana interaksinya terhadap saluran informasi atau pengetahuan baru yang potensial.

Secara individu, interaksi yang dilakukan oleh pelaku industri Sarung Majalaya masih sangat terbatas. Mereka tidak melakukan komunikasi dengan sumber pengetahuan baru, seperti pembeli yang menggunakan sarung yang diproduksi (end-user). Pembeli merupakan salah satu sumber pengetahuan baru yang penting bagi produsen (Chen et al., 2009; Cohen \& Levinthal, 1990; Malmberg et al., 1996). Hal ini terjadi karena pada umumnya, pelaku industri sarung menjualnya kepada pengumpul atau toko sarung milik orang lain sehingga mereka tidak dapat secara langsung mendengarkan pendapat dari pembeli terkait produk sarung yang dibelinya atau informasi lainnya seperti warna atau motif apa yang sedang banyak dicari oleh pengguna sarung saat ini. Informasiinformasi tersebut tentunya memiliki peran penting sebagai dasar pelaku industri Sarung Majalaya untuk meningkatkan kualitas atau keunggulannya di antara sarung-sarung lainnya.

Berdasarkan hasil wawancara yang dilakukan, pelaku usaha cenderung tidak membangun jejaring dengan pembeli yang baru. Mereka mempertahankan pembeli besar yang merupakan pelanggan yang dimiliki dari generasi sebelumnya. Berdasarkan pernyataan dari perwakilan Dinas Perdagangan dan Perindustrian Kabupaten Bandung, terdapat pelaku industri Sarung Majalaya yang terikat kesepakatan dengan beberapa pengumpul untuk hanya menyediakan sarung kepada pengumpul tertentu saja sehingga pelaku industri tidak dapat menjual kepada pengumpul lainnya. Hal tersebut juga tentunya membatasi peluang saluran informasi baru. Selanjutnya, kemudahan untuk mencari informasi-informasi menarik melalui internet juga ternyata belum dimanfaatkan secara maksimal oleh pelaku industri Sarung Majalaya. Mengingat mayoritas pelaku berusia di atas 45 tahun, penggunaan internet untuk mencari informasi tersebut menjadi tantangan tersendiri bagi mereka.

Selanjutnya, yang menghambat masuknya informasi ke dalam klaster adalah lingkungan Kecamatan Majalaya yang tidak memadai. Malmberg et al., (1996) menyatakan bahwa informasi dapat masuk dan berkembang jika suatu kawasan memiliki infrastruktur yang memadai. Dengan ketersediaan infrastruktur yang baik, suatu kawasan dapat menarik investasi untuk pengembangan infrastruktur lainnya di bidang pendidikan, penelitian, teknologi dan lainnya yang memiliki peran dalam membawa dan memproduksi informasi baru. Kondisi jalan yang dianggap belum cukup baik, pengelolaan lingkungan yang belum mendukung, menyebabkan Kecamatan Majalaya tidak cukup menarik untuk menangkap investasi-investasi pada bidang tersebut. Bahkan, kondisi ini menyebabkan Kecamatan Majalaya tidak menjadi pilihan utama tenaga 
kerja di bidang tekstil untuk bekerja, mengingat upah yang murah. Oleh karena itu, pelaku usaha industri Sarung Majalaya cenderung mencari tenaga kerja tanpa persyaratan khusus. Di sisi lain, keluar masuknya tenaga kerja terampil dan berpendidikan bermanfaat sebagai pembawa informasi baru (Dahl, 2002). Tidak heran, jika pelaku industri Sarung Majalaya sangat menginginkan adanya sekolah menengah kejuruan di bidang tekstil sebagai upaya mendapatkan tenaga kerja yang terampil.

Pada tabel selanjutnya dapat dilihat ringkasan terkait pengaruh kondisi dari kemampuan individu dan lingkunan dalam memperoleh informasi dan pengetahuan baru terhadap difusi pengetahuan di dalam klaster industri Sarung Majalaya. Penelitian ini mendapatkan bahwa baik secara individu dan lingkungan, kemampuan dalam memperoleh pengetahuan baru sangat terbatas sehingga penyebaran, pembelajaran, dan pemanfaatan pengetahuan baru di dalam klaster tidak maksimal. Hal tersebut disebabkan oleh interaksi yang kurang antara pelaku industri dengan sumber pengetahuan baru. Selanjutnya adalah faktor infrastruktur yang belum mampu mengalirkan dan mengelola pengetahuan baru dari luar klaster.

Tabel 1. Dampak Kemampuan Memperoleh Pengatahuan Baru terhadap Proses Difusi Pengetahuan (Hasil Analisis, 2019)

\begin{tabular}{|l|l|}
\hline Kondisi Kemampuan & \multicolumn{1}{|c|}{ Dampak } \\
\hline $\begin{array}{l}\text { Interaksi individu } \\
\text { pelaku industri dengan } \\
\text { sumber pengetahuan } \\
\text { baru yang terbatas }\end{array}$ & $\begin{array}{l}\text { Terbatasnya } \\
\text { pengetahuan baru yang } \\
\text { dimiliki oleh pelaku } \\
\text { industri }\end{array}$ \\
\hline $\begin{array}{l}\text { Infrastruktur kawasan } \\
\text { yang tidak memadai } \\
\text { dalam menarik } \\
\text { pengetahuan baru } \\
\text { masuk ke dalam } \\
\text { klaster }\end{array}$ & $\begin{array}{l}\text { Pengetahuan baru tidak } \\
\text { masuk ke dalam klaster } \\
\text { dan berkembang di } \\
\text { dalam klaster }\end{array}$ \\
\hline
\end{tabular}

\subsection{Kemampuan Asimilasi dan Transformasi Pengetahuan}

Asimilasi dan transformasi pengetahuan menekankan integerasi pengetahuan luar dengan pengetahuan lokal industri yang kemudian dimanfaatkan untuk tujuan industri tersebut (Chen et al., 2009; Cohen \& Levinthal, 1990; Hoarau, 2014; Mitra, 2000). Asimilasi dan transformasi pengetahuan akan terjadi jika terdapat adaptasi yang bersifat akumulasi dari berbagai pihak sehingga pada proses ini kapasitas sosial menjadi suatu hal yag juga penting (Klarl, 2009). Komunalitas dengan Interaksi tatap muka antara pelaku usaha dapat mendorong terjadinya pembelajaran kolektif (Hoarau, 2014). Berdasarkan hal tersebut, selain dibutuhkannya saluran informasi baru masuk ke dalam klaster industri Sarung Majalaya, bagaimana pengetahuan yang masuk dipelajari bersama-sama oleh pelaku industri juga perlu dilihat.

Penelitian ini mendapatkan bahwa "luapan" informasi di dalam klaster tidak terjadi sehingga tidak ada pembelajaran kolektif. Pengetahuan baru cenderung tidak berpindah dari satu pelaku industri ke pelaku lainnya. Hal ini ditunjukan dengan tidak adanya komunikasi yang intensif antar pelaku industri. Kompetisi yang agresif di dalam klaster Sarung Majalaya ternyata membuat pelaku industri untuk membatasi komunikasinya dengan pelaku lain. Kondisi ini dapat dilihat pada kutipan wawancara dengan pelaku industri berikut: kita bersaing dengan keluarga sendiri, kita bahkan bisa saling tonjok saat permintaan sedang tinggi. Kita itu sebenernya mendiri dan egois jadi kita gak pernah berbagi informasi tentang bisnis. Keberadaan asosiasi pelaku industri sarung juga dianggap belum mampu mendorong terjadinya pembelajaran kolektif. Padahal, komunitas ini berpotensi sebagai wadah bagi pelaku industri Sarung Majalaya untuk berbagi pengalaman yang dapat menjadi pembelajaran bagi masing-masing pelaku industri Sarung Majalaya serta mendorong terjadinya kolaborasi antar pelaku industri. Selain itu, pembelajaran kolektif antara pegawai dan pemilik industri sarung juga tidak berkembang. Dalam suatu klaster industri, keberadaan tenaga kerja sebenarnya berkontribusi terhadap asimilasi dan transformasi pengetahuan baru ke dalam produk. Sayangnya, meskipun mereka memiliki tenaga kerja yang didominasi oleh usia produktif dan pengalaman yang beragam, pembelajaran dan keputusan-keputusan terkait pengembangan produk terjadi pada lingkup keluarga. Mengingat industri Sarung Majalaya 
merupakan usaha keluarga, peran keluarga menjadi sangat dominan.

Dua situasi tersebut menunjukan pelaku industri memiliki individualisme yang tinggi. Tingginya individualisme mendorong pengetahuan baru tidak tersebar dan pada akhirnya tidak berkembang di dalam klaster. Tingginya individualisme yang tinggi atau rendahnya ikatan sosial sebenarnya bukan suatu masalah dalam perkembangan inovasi pada suatu kawasan. Florida (2003), dalam tulisannya menemukan bahwa di perkotaan, rendahnya ikatan sosial merupakan suatu kondisi yang efektif bagi berkembangnya inovasi. Namun, kasus tersebut ditemukan pada kawasan dengan infrastruktur yang memadai serta kelembagaan di bidang penelitian dan pengembangan yang baik. Selain itu, meskipun pelaku memiliki indivisualisme yang tinggi, kolaborasi tetap terjadi dengan baik. Berbeda dengan klaster Sarung Majalaya, selain infrastruktur yang belum mendukung, individualisme yang tinggi belum disertai dengan kasadaran terhadap pentingnya kolaborasi. Temuan-temuan Chen et al., (2009) mendapatkan bahwa budaya kolaborasi merupakan salah satu modal penting untuk menciptakan lingkungan yang kondusif terhadap berkembangnya inovasi. Meskipun sebenarnya, kompetisi tetap terjadi dan kolaborasi tidak mengurangi sengitnya kompetisi antar pelaku.

Selanjutnya adalah transformasi pengetahuan. Pada kasus klaster industri Sarung Majalaya, sebenarnya ditemukan bahwa pelaku industri dapat meniru motif sarung lain, terutama sarung dengan merek-merek populer. Hal tersebut menunjukan bahwa mereka sebenarnya mampu menggunakan pengetahuan mengenai motif lain dan disesuaikan dengan kemampuan mereka sehingga mereka dapat memproduksi sarung dengan motif yang sama. Sayangnya, hal ini tidak memberikan manfaat yang signifikan kepada pelaku industri. Berbeda jika pelaku industri mengembangkan motif baru. Situasi ini diakui baik oleh pelaku industri Sarung Majalaya dan pemerintah Kabupaten Bandung. Mereka menyadari bahwa kelemahan utama pelaku industri Sarung Majalaya adalah mengembangkan gagasan baru terhadap produk Sarung Majalaya. Berdasarkan hal tersebut, transformasi pengetahuan terhadap produk sarung belum memberikan nilai-nilai baru terhadap pengetahuan tersebut sehingga yang dilakukan pelaku industri Sarung Majalaya masih menunjukan prilaku peniru. Sedangkan, meniru bukan bagian dari inovasi (Bass, 1969).

Pada tabel selanjutnya dapat dilihat bahwa kondisi kemampuan dalam asimilasi dan transformasi pengetahuan belum mampu mendukung proses difusi pengetahuan yang melahirkan inovasi. Tingginya individualisme menghalangi tersebarnya informasi dari satu pelaku ke pelaku lainnya di dalam klaster. Hal tersebut menyebabkan luapan informasi sebagai tahap penting dalam difusi pengetahuan tidak terjadi. Selanjutnya adalah kemampuan transformasi pengetahuan yang baru mencapai tahap meniru menyebabkan nuansa kebaruan produk di dalam klaster belum berkembang dan menjadi hal yang memotivasi pelaku industri untuk melakukan inovasi pada produknya.

Tabel 2. Dampak Kondisi Kemampuan Asimilasi dan Transformasi terhadap Difusi Pengetahuan (Hasil Analisis, 2019)

\begin{tabular}{|l|l|}
\hline Kondisi Kemampuan & \multicolumn{1}{c|}{ Dampak } \\
\hline $\begin{array}{l}\text { Adaptasi kolektif yang } \\
\text { tidak memadai karena } \\
\text { tingginya } \\
\text { individualisme pelaku } \\
\text { industri Sarung } \\
\text { Majalaya }\end{array}$ & $\begin{array}{l}\text { Informasi atau } \\
\text { pengetahuan baru sulit } \\
\text { "meluap" sehingga tidak } \\
\text { dimanfaatkan oleh } \\
\text { pelaku industri lainnya }\end{array}$ \\
\hline $\begin{array}{l}\text { Transformasi } \\
\text { pengetahuan baru } \\
\text { sampai pada tahap } \\
\text { meniru }\end{array}$ & $\begin{array}{l}\text { Tidak ada contoh } \\
\text { pengembangan produk } \\
\text { yang dilihat dan } \\
\text { memotivasi pelaku } \\
\text { industri di dalam klaster } \\
\text { untuk melakukan } \\
\text { perubahan }\end{array}$ \\
\hline
\end{tabular}

\section{SIMPULAN}

Klaster industri Sarung Majalaya menunjukan bahwa kedekatan spasial bukan satu-satunya faktor yang mendorong berkembangnya inovasi yang dihasilkan dari proses difusi pengetahuan dalam suatu klaster. Terdapat faktor penting lain yang bersifat nonfisik yang mempengaruhi proses difusi pengetahuan tersebut, yaitu kemampuan individu dan lingkungan dalam memperoleh 
pengetahuan baru serta kemampuan individu dan kolektif dalam asimilasi dan transformasi pengetahuan baru. Terbatasnya inovasi produk yang terjadi di dalam klaster industri Sarung Majalaya terjadi karena secara individu dan lingkungan belum mampu memperoleh pengetahuan baru dengan maksimal. Padahal, dalam proses difusi pengetahuan, aliran pengetahuan baru merupakan kebutuhan dasar. Keterbatasan tersebut disebabkan oleh kurangnya interaksi antara pelaku industri dengan sumber pengetahuan baru dari luar klaster serta infrastruktur yang tidak memadai menyebabkan pengetahuan dari luar klaster sulit untuk masuk dan berkembang di dalam klaster industri Sarung Majalaya. Tingginya individualisme pada pelaku industri juga ternyata menghambat terjadinya luapan pengetahuan. Selain itu, tahap asimilasi yang baru mencapai meniru produk lain tanpa memberikan nilai baru menciptakan lingkungan yang belum mampu memotivasi pelaku di dalamnya untuk melakukan perubahan terhadap produknya.

Untuk mendorong inovasi, kebijakan daerah seharusnya mampu membuka peluang pelaku ekonomi di dalam klaster industri untuk mengakses informasi atau pengetahuan baru dari luar klaster seluas-luasnya. Sebagaimana yang didapatkan dalam penelitian ini, kebijakan dapat membuka aliran pengetahuan luar ke dalam klaster dengan menyediakan infrastruktur dasar yang memadai serta mulai berinvestasi di bidang pendidikan, penelitian dan pengembangan yang berkaitan dengan industri yang berkembang di dalam klaster. Selain itu, penelitian ini juga menemukan bahwa kapasitas secara kolektif memiliki peran penting dalam difusi pengetahuan. Oleh karena itu, kapasitas sosial melalui peningkatan kapasitas asosiasi di dalam klaster juga perlu ditingkatkan agar mampu berperan sebagai wadah yang memotivasi pelaku industri di dalam klaster untuk berinovasi.

\section{REFERENSI}

Aiginger, K., \& Rossi-Hansberg, E. (2006). Specialization and concentration: A note on theory and evidence. Empirica, 33(4), 255-266.
Bass, F. M. (1969). A new product growth for model consumer durables. Management Science, 15(5), 215-227.

Chen, Y.-S., Lin, M.-J. J., \& Chang, C.-H. (2009). The positive effects of relationship learning and absorptive capacity on innovation performance and competitive advantage in industrial markets. Industrial Marketing Management, 38(2), 152-158.

Cohen, W. M., \& Levinthal, D. A. (1990). Absorptive capacity: A new perspective on learning and innovation. Administrative Science Quarterly, 128-152.

Dahl, M. S. (2002). Embedded knowledge flows through labor mobility in regional clusters in Denmark. DRIUD Summer Conference on "Industrial Dynamics of the New and Old Economy-Who Is Embracing Whom.

Florida, R. (2003). Cities and the creative class. City \& Community, 2(1), 3-19.

Henderson, J., \& Weiler, S. (2010). Entrepreneurs and job growth: Probing the boundaries of time and space. Economic Development Quarterly, 24(1), 23-32.

Hoarau, H. (2014). Knowledge acquisition and assimilation in tourism-innovation processes. Scandinavian Journal of Hospitality and Tourism, 14(2), 135-151.

Hotho, J. J., Becker-Ritterspach, F., \& SakaHelmhout, A. (2012). Enriching absorptive capacity through social interaction. British Journal of Management, 23(3), 383-401.

Klarl, T. (2009). Knowledge Diffusion Processes: Theoretical and Empirical Considerations.

Lauwis, M. (2016). Identifikasi Wilayah dan Karakteristik Megaregion di Indonesia Berdasarkan Aktivitas Pergerakan Barang (Studi Kasus: Wilayah Operasi PT JNE di Jawa bagian Barat). Tugas Akhir Perencanaan Wilayah dan Kota ITB.

Lestari, M. D. A. B., \& Siagian, M. C. A. (2018). Perancangan Sarung Majalaya Untuk Busana Ready To Wear. EProceedings of Art \& Design, 5(3).

Malmberg, A., Sölvell, Ö., \& Zander, I. (1996). Spatial clustering, local accumulation of knowledge and firm competitiveness. Geografiska Annaler: Series B, Human Geography, 78(2), 85-97. 
Mitra, J. (2000). Making connections: Innovation and collective learning in small businesses. Education+ Training.

Porter, M. E. (2000). Location, competition, and economic development: Local clusters in a global economy. Economic Development Quarterly, 14(1), 15-34. 